\title{
JEGYZETEK A TERÜLETI TERVEZÉS ÚJ, RÉGI KIHÍVÁSAIHOZ ${ }^{1}$
}

\author{
(Remarks on Recent and Long-standing Challenges of Regional \\ Planning)
}

\section{RECHNITZER JÁNOS}

Szabad-e egy újdonságot, egy eddig nem alkalmazott, vagy másként ismert rendszert már a megszületése utáni pillanatoktól kezdve megújításra ösztönözni? Azt hiszem szabad, sőt szükséges. Hiszen éppen a kezdeti időszakban alakulnak ki a rendszer elemei, szervezödnek meg a technikák a müködésre, formálódnak ki az ítéletek és a megszokások, s mindezek révén kap teret az elfogadottság, a szerep, egyben a hatás és az érvényesülés.

A közel egy esztendős múlttal rendelkező területi tervezést tekintjük annak a rendszernek, aminek a születésével együtt kell a megújítását is megkezdeni, vagy éppen folytatni. A képzavar feloldását kezdjük azzal, hogy már a rendszerváltozás elött is létezett területi tervezés, annak mindkét ága: a fejlesztés szempontú társadalmi-gazdasági és rendezés szemléletủ tervezés is. Az alkotóelemek azonban nem voltak kapcsolatban az állami erőforrások elosztásával, abban egyértelmüen a szektorális elvek érvényesültek. A korábbi területi tervezési rendszer nem alulról épitkezett. Ugyan területi szinten kísérelte meg visszatükrözni az akkori ideológiai modellben megfogalmazott igényeket, valamilyen - laza - próbálkozást téve a területi, helyi (döntően megyei) érdekek érvényesítésére.

A rendszerváltozás után a tervezést - minden vonatkozásban, így területi szinten is - a politika - s az arra érzékeny szakma is - sutba dobta. Készültek ugyan fejlesztési koncepciók a társadalmi-gazdasági szempontból hátrányos helyzetủ térségekre (Borsod, Nógrád, Szabolcs-Szatmár, Békés megye), de ezek célja a regionális válságok kezelése, azok számtalan, vagy egyetlen feloldási módjának ajánlása volt. Nagyobb számban kerültek kidolgozásra - az alulról jövő kezdeményezések alapján - kistérségi fejlesztési koncepciók, amelyeket nemzetközi programok is támogattak (Phare program). Az első időszakban még a külföldi szakértők játszották a főszerepet a kidolgozásukban, majd egyre több hazai szakember jelent meg a területi tervezés „piacán”. A tervek megvalósításához csekély mértékü központi források álltak rendelkezésre, viszont több hátrányos helyzetü térségben az elképzelt programok - részben - finanszírozásra kerülnek. (Tanulságos lenne, ha e forrásokról és felhasználásukról átfogó képünk lenne!)

Az első időszakban - 1996-ig - lényegében tehát nem beszélhettünk a területi tervezésrôll, annak inkább az erősebb, rendezési tervezés oldala müködött, maradt fenn - döntően a KTM támogatása mellett - míg a stratégiaépítést szolgáló gazdasági-társadalmi tervezés, vagy pontosabban fejlesztés-orientált tervezés csupán néhány módszertani kísérletet tudhatott magának, ugyancsak a KTM támogatásával. (Ezek a próbálkozások döntően a nagytérségi területfejlesztést szolgálták, így az Alföldre, a Dél-Dunántúlra és az Északnyugat-Dunántúlra készült egy-egy 
területfejlesztési koncepció, lehetőséget nyújtva kutatóknak az egyes tervezési eljárások kidolgozására és tesztelésére.)

A korszakváltást a Területfejlesztésrōl és területrendezésrôl szóló törvény (1996. XXI. tv.) jelentette a területi tervezésben. A törvény elöírja, hogy a területfejlesztési koncepció „,... az ország, illetve egy térség átfogó fejlesztését megalapozó és befolyásoló tervdokumentum, ami meghatározza a térség hosszú távú, átfogó fejlesztési céljait, továbbá a fejlesztési programok kidolgozásához szükséges irányelveket, információkat biztosít az ágazati és a kapcsolódó területi tervezés és fejlesztés szereplöi számára" (5.§ m.). Hasonlóképpen meghatározza a területfejlesztési program fogalmát is, ami "a területfejlesztési koncepció alapján kidolgozott középtávú cselekvési terv, amely stratégiai és operatív programokra épül " (5.§ m.).

\section{Az Országos Területfejlesztési Koncepcióról}

A törvény kötelezövé teszi az Országos Területfejlesztési Koncepció (OTK) kidolgozását, amit az országgyülés fogad el, s ennek alapján történik meg a területi politika irányelveinek, céljainak és hosszú távú prioritásainak a meghatározása. Az OTK tekinthetö a területi tervek legmagasabb szintjének, egyben azok összegzésének, illetve az OTK-ban megfogalmazottak jelentik a további területi szintek fejlesztésének alapját, irányait.

Az országos, vagy nemzeti területfejlesztési koncepciók kidolgozásának gyakorlata az Európai Unió országaiban más és más. A területi politika nagyobb hagyományaival rendelkezỏ országokban (Franciaország, Németország, Hollandia, Nagy-Britannia) rendszeresen készülnek, különböző időtávokra (eltérö, a tervezési gyakorlat függvénye általában 7-10 év között) nemzeti, országos területfejlesztési tervek. Európa további országaiban, föleg a mediterrán térségben az ágazati tervek rendelkeznek területi vetülettel, átfogó nemzeti területi tervek eddig nem készületek, azok előkészítése azonban megkezdődött. Az Unió új tagországai (Ausztria, Finnország, Svédország) - a területi politika meghatározó szerepe miatt rendelkeztek országos területfejlesztési koncepciókkal, sőt azokat a felkészülés idöszakában már az új elvárásoknak megfelelően módosították, gondolták át újra.

$\mathrm{Az}$ országra kidolgozott területfejlesztési koncepció, mint a területi politika irányait meghatározó alapdokumentum, akkor tudja tényleges hatásait érvényesíteni, ha az kapcsolódik egy nemzeti fejlesztési tervhez. A nemzeti közmegegyezésen alapuló jövőkép meghatározza az adott ország hosszú távú fejlesztési irányait, annak szektorális súlypontjait, megjelölve egyúttal a forrásokat, valamint azok koordinációjának alapelveit. A területfejlesztési koncepció hivatott a nemzeti program területi összefüggéseinek megjelenitésére, azaz kijelölni, hogy a nemzet jövöbeli fejlödési irányai milyen térségi dimenziókban értelmezhetök, azok szektorális rendszerének területi szinten milyen fejlesztési céljai vannak, s ehhez miként kell az eszköz- és intézményrendszert alakítani, megújítani.

Hiányosságnak tarjuk, hogy az országos területfejlesztési koncepció, mint a hosszú távú térszerkezet alakításának stratégiája, nem épül nemzeti prioritásokra, nem egy elfogadott nemzeti jövőkép térségi összefüggéseit jeleníti meg. A koncepció légüres térben lebeg, hiszen a generáló szerepét nem képes betölteni, 
nincsenek kötödési pontjai, így aztán megmarad az általános térszerkezeti célok megjelenitésénél, illetve az ágazati fejlesztési célok összerendezésénél, azok lehetséges területi hatásainak érvényesítésénél.

A jelenlegi koncepció még nem tükrözi azokat az elvárásokat, igényeket, amelyeket az EU az egyre szélesebb európai együttmüködés térbeli hatásainak elemzésére és értékelésére szán az ezredforduló után. Megjelennek ugyan az EU regionális politikai alapelvei, de ezek közül a koncentráció elve kap prioritást, hiszen a különféle típusú célterületek lehatárolása megtörténik, azok fejlesztési inkább általánosabb, EU gyakorlat szerinti - elveit kijelöli. Viszont nem tükrözi a koncepció a programozás elvét: a tervezés és az intézkedések sorozatát, a különféle területi szintek terveinek egymásra épülését, kölcsönös meghatározottságát. Adós marad továbbá az addicionálás valós rendszerének meghatározásával is, azaz egyértelmü eröforrásokat nem rendel a célokhoz, figy nem erösíti a partnerkapcsolatokat, annak eszköz- és intézményrendszerét nem határozza meg.

Az országos területfejlesztési koncepcióban nem került hangsúlyozásra, és egyben a célok között csak áttételesen jelennek meg a hazai és az európai regionális folyamatok közötti sokoldalú összefüggések. Nem találunk egyértelmü stratégiát arra, hogy Magyarország szerepe és lehetöségei miként alakulnak az európai térfolyamatok átrendezödésében (Európa 2000+, 1994. évi lipcsei és strassburgi miniszteri tanácskozás ajánlásai. Az sem derül $\mathrm{ki}$, hogy hazánknak mi a valós szerepe és küldetése, éppen az EU integráció következében Közép-Európában, a Kárpát-medencében, a Balkán irányában, valamint Kelet-Európa felé (különösen Ukrajna és Oroszország irányába) kellene ezt meghatározni.

Az OTK Európára tekint, de kimondottan Nyugat-Európára, s a területi politikát ennek megfelelően egypólusúvá teszi. Nincsenek üzenetei arra vonatkozóan, hogy hazánk hét országgal határos, ezek közül egy tagja az Uniónak (Ausztria), egy csatlakozásának (Szlovénia) előkészítése megkezdődik, míg a többi öt ország (Szlovákia, Ukrajna, Románia, Szerbia, Horvátország) esetében különféle szinten állnak a kapcsolatok az Unióval, s vélhetően csak a következö - nem belátható idön belüli - fordulóban kapcsolódhatnak valamilyen formában a közösséghez. Az ország számára tehát egy kétpólusú területi politika kidolgozására lenne szükség. Az egyik irány - az EU alapelvek szerint - az integrációs folyamatokra késziteni fel a területi egységeket. A másik vonatkozásban az országot, s annak térszerkezetét úgy kell alakítani, hogy az Európa két nagytérségének kapcsolódási pontja, forditó korongja lehet.

Szorgalmazni kell tehát az új térszerkezeti és - szervezési rendszereket, amelyek éppen az elmaradott térségek számára ezzel az új közvetítő szerepkörön keresztül nyújtanak megújitási lehetőségeket. Napjainkra egyértelmüvé válik, hogy az osztrák-magyar határ menti térségben az évtized elején megkezdödött dinamikus folyamatok - különféle intenzitással - átterjednek az ország többi határmenti régiójába, csak fordított elöjellel, azaz a kezdeményezö szerepet már a magyar oldal képviseli. Mindez új felzárkózási, megújitási stratégiát kínál a jelenleg kedvezötlen adottsággal rendelkezö térségeknek, ami egyben mérsékelheti az országon belüli - erösödö - területi feszültséget. A kétpólusú regionális politika új dimenziókat nyithat meg a területfejlesztés számára, egyben a területi szintü stratégiaépités mozgásterét is jelentősen bövitheti. 
Az Ország Területfejlesztési Koncepció elveiben és feldolgozásaiban követi tehát az európai gyakorlatot, azonban folyamatos megújitása, átalakítása szükséges. Figyelembe kell venni, hogy az egységes európai térre egyre több új koncepció készül, ezek szellemében, gondolkodásmódjában kell értelmezni, és feldolgozni a hazai térszerkezet jellemzöit, illetve az ország új és régi nagytérségi kapcsolatait. A nemzeti fejlesztési terv kidolgozását mindez még erőteljesebben szorgalmazza, hiszen az ország egészének küldetése, mind a makroregionális, mind a multiregionális összefüggéseket is meghatározza, annak irányait kijelöli.

\section{A térségek tervei}

A területi tervezés következö szintje az említett törvény alapján $a$ megyei szintü területfejlesztési koncepció (13. § (2) b.), amelyet a megyei területfejlesztési tanács dolgoz ki, s fogad el. A megyei önkormányzat feladataként írja elö a törvény (11. § (1) b.), hogy " ... a hosszú távú elörejelzések alapján területileg összehangolja a kötelezően ellátandó feladatait, különösen az oktatás, a közmüvelödés, az egészségügyi, a szociális, az épitett és természeti környezet védelmével kapcsolatos, az idegenfogalmi, illetve a közszolgáltatási feladatait, biztosítja azok összhangját a megyei gazdaságfejlesztési és foglalkoztatás-politikai koncepciókkal". Továbbá " ... állást foglal a megyei területfejlesztési tanács döntését megelözően a megye hosszú távú területfejlesztési koncepciójáról, a megyei területfejlesztési tanács döntését követöen elfogadja annak önkormányzatra vonatkozó részét. " (11. § (2.) a.).

A törvény tehát a területfejlesztési koncepciót a megyei területfejlesztési tanács hatáskörébe utalja, mig annak számos elemét viszont a megyei önkormányzathoz rendeli. A tervezés összhangját kölcsönös véleményezéssel, illetve a testületek közötti szervezeti és személyi kapcsolatokkal kívánja megoldani.

Szükséges annak regisztrálása is, hogy térségi (regionális) szinten a törvény nem írja elö a területfejlesztési koncepció kidolgozását, azt csupán a két kötelezően (15. § (2.)) létrehozandó regionális fejlesztési tanács (Budapest és agglomerációja, Balaton) esetében említi meg.

A területi szintü tervezés gyakorlata az Európai Unió tagállamaiban eltérö. Az megállapitható, hogy a területi terveket és azokra épülő programokat az elmúlt 5-7 évben (1988-tól) a különféle területi egységeket igyekeztek a támogatásokhoz, s azok alapját jelentö célterületi lehatárolásokhoz igazítani. A NUTS II. szint, mint a regionális fejlesztés meghatározó tere vált általában elfogadottá, erre vonatkozóan készültek el a területfejlesztési stratégiák.

$\mathrm{Az}$ ok egyszerü, hiszen egy nagyobb területi dimenzióban jobban tervezhetök a különféle folyamatok, az infrastrukturális rendszerek fejlesztése egyértelmüen meghatározhatók, a gazdaság karakterei árnyaltabbak, azok helyettesithetősége és kapcsolatai feltárhatók, a településhálózat rendszert alkot, a centrumok valós funkciói kimutathatók, a régión belül a térségek jellege meghatározható, s mindehhez hozzárendelhetö valamilyen igazgatási szint is, ami lényegében ellenörizheti a megvalósítást, illetve fogadhatja a támogatásokat. A regionális szinten belül lehet elkülöníteni azokat a speciális területi egységeket, amelyek valamilyen egyedi karakterrel rendelkeznek (NUTS III.), ezekre irányulnak a sajátos 
fejlesztési célkitüzések $(2,5 \mathrm{a}, 5 \mathrm{~b}, 6)$. Magára az egész régióra az egyedi (3., 4 ., célkitūzések illetve Közősségi Kezdeményezések) támogatások lehetnek érvényesek, amelyek valamilyen tevékenységhez, vagy funkcióhoz kötödnek (pl. határmentiség, fiatalok és nổ foglalkoztatása, szerkezetváltás a bányászat, az acélgyártás, vagy a textilipar térségeiben, a kis- és kőzépvállalkozások támogatása az elmaradott térségekben, a nagyvárosok megújitása, stb.).

A hazai gyakorlat napjainkban alakul ki. Jelenleg megyei szinten készültek csak és kerületek elfogadásra területfejlesztési koncepciók, azok ősszeállitásának módszertana most formálódik, vannak igéretes törekvések, még nem lehet határozott véleményt mondani a tervek valós tartalmáról, jellegéröl, s egyáltalán nem értékelhetö megvalósítás, de még a programozás sem.

A stratégiák kidolgozásának, pontosabban épitésének időszaka kezdödött meg. Fontos művelet ez, hiszen megtörténik az eröforrások felmérése és rendszerezése, értékeljük nemzetközi és országos vonatkozásban a területi egység helyzetét, funkcióit, és megkezdödőtt az ismert és a kevésbé ismert belső adottságok új szempontú feltárása. Közös, együttes gondolkodás indul el a különféle szereplök között, s mindezek közben a területi identitás is erösödik. A küldetés feltárásának, meghatározásának izgalmas korszakát éljük tehát. A felszinre kerülnek a különféle szabályozások ellentmondásai, a szereplök lehetséges mozgástere, az érdekellentétek, s mindazok a feszültségek, amik a hazai lopakodó területi decentralizációból következnek.

A következökben néhány, a stratégia-épitéssel kapcsolatos kérdésröl adunk áttekintést, hogy ezzel is hozzájáruljuk a formálódó területi tervezés gondjainak rendszerzéséhez, egyben a megújitásához adalékokat adjuk.

\section{$A$ rész és az egész}

Az megállapitható, hogy nem a részek összegébôl fog összeállni az ország, azaz a megyei tervek és elképzelések egyùttese nem lesz képes sem a térségi (regionális), sem országos rendszert alkotni, így feltétlenül szükséges egy közvetitö szint, azaz a térségi (regionális) területfejlesztési stratégia kialakitása. A megújult hazai területi tervezés nem alulról épitkezett. Ezt nem is tudta volna megtenni, hiszen a területi politika alakitását meghatározó törvény elfogadásának elökészitésével párhuzamosan (1995 nyarán) kezdödtek meg az országos területfejlesztési koncepció kidolgozásának munkálatai, s azt még napjaikban (1997. április) sem fogadták el. Megyei fejlesztési tervek ebben az időben még nem voltak, így az OTK egyeztetése a megyékkel csupán a „vágyak birodalmára" épülhetett volna, vagy épült (?).

A tervezési elvek és módszerek nem egységesek, a szabályozás - helyesen általános keretek között határozta meg a koncepciók tartalmát, annak felépitését. Más-más gondolkodásmóddal rendelkezö tervezök, területi elemzök és kutatók, más és más közelítéseket alkalmaznak a stratégiák megalapozásában, a koncepcióalkotásban, a célok és célcsoportok kijelölésében.

A megyékben a tervezettség szintje nagyon különbözö. Voltak megyék - kutatási tapasztalataink alapján - ahol már a kilencvenes évek elején megkezdődött a különféle funkciók, ellátási rendszerek területi szintũ fejlesztési koncepcióinak kidolgozása, a kistérségi szerveződések megalakultak és többé-kevésbé ezek 
rendelkeztek - az évtized közepére - fejlesztési elképzelésekkel. Másutt viszont nem voltak szektorális fejlesztési tervek, a kistérségek patronálása nem történt meg, s így a gyenge szervezettség együtt járt a fejlesztési koncepciók hiányával.

A módszerek különbségei az ũzenetek - magasabb, vagy alacsonyabb területi szint tervei - hiánya, a különféle ágazati koncepciók, azok megléte esetén is a tarka helyzetfeltárások és jövőképek nem tették lehetôvé, hogy mindezek integrációjaként alakuljon a stratégia, s azokból aztán egy nagyobb területi (megye, régió) egység fejlesztési célrendszere álljon össze.

A területi tervezési rendszerben a tervek egymásra épültségének csak az általános elvei tisztázottak, sem a tartalmi elemek, sem pedig a módszertani meghatározók nem ismertek, azok valójában kidolgozásra szorulnak. Az európai gyakorlat üzenetei a regionális dimenzió erösítését ösztönözik, míg a megyei szintnél (NUTS III.) elsődlegesen a területi specialitások, sajátosságok megjelenitése emelendö ki (2., 5b. célterületek). A kistérségi szint szerepét a terulleti tervezésben annyiban lehet érvényesíteni, hogy ebben a viszonylatban szükséges a konkrét fejlesztési programokat meghatározni és kidolgozni, amelyeknek harmonizálniuk kell a térségi (regionális) szinttel, ugyanakkor a célterületi támogatásoknak, azok felhasználásának a programterei is egyben.

\section{A területi egység, mint sziget}

A területi tervezés során szembekerülhetünk a sziget-effektussal. A térszerkezetben kialakulnak egybefüggő rendszerek, olyan egymásba füzōdō struktúrák, amelyeket nem lehet valamilyen mesterséges határ mentén megszakitani, megtörni. Ilyenek az infrastrukturális rendszerek, a településhálózat elemei, a természeti-táji struktúrák, nagyvárosok, vagy kisebb centrumok vonzáskörzetei, illetve különféle szervesen együttélö, közigazgatási határokat nem érzékelö tevékenységek, intézmények funkció terei. Minél tágabb a területi dimenzió, annál könnyebben lehet feloldani a sziget-effektust, annál kevesebb a területi rendszerelem, amelynél a határok akadályt jelentek az elemzésben és a tervezésben.

Ugyanakkor számolni kell az ellentétes hatással is, vagyis azzal, hogy a nagyobb térben a fejlesztés szereplöi ugyan megtalálhatók, de azokhoz több intézmény rendelhetö, így nehéz megtalálni a tényleges megvalósítókat, a célok valós hordozóit, azokat, akiknek érdeke az adott stratégiai cél gondozása. A megyei és a térségi (regionális) fejlesztési koncepciók esetében találkozunk ezzel az ellentmondással. Egyik oldalról szükséges a térségi (regionális) kitekintés, illetve térségi (regionális) szinten meghatározni egyes stratégiai célokat. A másik oldalon viszont egy-egy funkcióra párhuzamosan több szereplö található, akiknek alapvetö érdeke a saját területi (megyei) egység, így a célok részben elsikkadnak, részben pedig párhuzamosságot mutatnak.

A térségi (regionális) szintŭ stratégiák azért is szükségesek, hogy a párhuzamosságok csökkenjenek, illetve bizonyos céloknak, s azokhoz rendelhetö intézmẻnyeknek a müködési tere szükségszerüen túllépjenek a megyehatárokon, azoknál jóval nagyobb terekben érvényesülnek. Tisztázásra szorul a közeli jövöben, hogy térségi (regionális) dimenzióban milyen fontosabb funkciók müködjenek, illetve ezekre a szintekre milyen feladatok telepitendōk. Ugyancsak nem kerülhetök 
meg a térségi (regionális) intézmények kialakítása, vagy legalábbis a központi kormányzat területi szerveiben a regionalizáció megkezdése.

A nemzetközi tapasztalatok - esetünkben Franciaországot kell alaposan tanulmányozni - alapján a regionalizáció 10-15 év alatt képes volt érzékelhető eredményeket elérni, mérsékelni a megyerendszerben kialakult beidegződéseket, valamiféle regionális identitást, $\mathrm{s}$ azzal együtt érdekeket megjeleniteni. A tervezésistatisztikai régiók létrehozása egy kezdő, óvatos lépés csupán, térségi fejlesztési koncepció eszköz és intézményrendszer nélkül viszont csupán irott malaszt marad.

\section{Stratégiai szereplök}

Alapvetö kérdés, hogy kinek készül a területfejlesztési koncepció, mennyiben érdekeltek a szereplök a kidolgozásban, a jövőépítésben. Nos, a tapasztalatok azt mutatják, hogy az aktivitás mérsékelt, mondhatni gyenge. Egyrészt, nem értik a szereplök a stratégia célját, többségük nem fogja be a területi egységet, a müködésében, a tevékenységében a megyei dimenzió nem jelenik meg. Gondolkodásukban és cselekedeteikben a lokalitás, $a$ helyi kérdések határozottabban vannak jelen, míg a megyei szint, s föleg a regionális dimenzió már nem értelmezhető. Másrészt, az érzékenység is gyenge más szektorok, tevékenységek problémái iránt. Azok hatásait a szereplök általánosan tekintik fontosnak (pl. környezet- vagy vidékfejlesztést), viszont ha a célok között e funkciók valamilyen módon sértik érdekszférájukat, máris kifogások sorozatával élnek, erősíteni igyekeznek saját pozíciójukat.

Ennek a természetes magatartásnak az oka abban keresendö, hogy nem állnak rendelkezésre biztos eszközök a koncepciók megvalósításához, nem egyértelmüek és világosak a központi források decentralizációnak szabályai, azok tervezhetösége rövid távon (két-három éves intervallumra) kevésbé biztosított. A különféle ágazati források megyén belüli elosztásánál még nem veszik figyelembe a területfejlesztési koncepciókat ( $\mathrm{pl}$. foglalkozatási alap decentralizált része), s végül az egyes szereplök (gazdasági szervezetek és önkormányzatok) a saját elképzeléseiket (terveiket, koncepciókat?) kísérlik meg mindenekfelett érvényesíteni. A szereplök többsége inkább forrásigénnyel lép fel a területfejlesztés felé, minthogy a partnerség elve alapján hozzájárulnának a közösen kimunkált és elfogadott célok (jövőkép) megvalósításához.

A területi identitás minden vonatkozásban gyenge. Elsödlegesen a megyei intézményi funkciókhoz kapcsolódó politikai szereplőkben, illetve azokat kiszolgáló hivatalokban, és intézményekben mutatható ki a megyéhez való határozott kötödés: A közszolgáltatás más szervezeteiben a „megye-kép" erőtlen, s a gazdasági szervezetekben nem szignifikáns tényezö. Mindezek után a regionalitás valami ködös, nehezen értelmezhetö zürzavar, ami még ráadásul nem köthetö semmilyen intézményhez, s egyben veszélyforrás is a megyei intézményi szereplőknek, hiszen saját létük esetleges felszámolását látják abban.

A stratégia határozott, jól kitapintható területi identitás nélkül nem életképes, nem válik a különféle jövőképek mozgatójává, eredőjévé. Hiába készül el, áll össze a stratégia, üres sablonok gyüjteménye marad a területi érdek, akaratok nélkül. A tapasztalatok azt mutatják, hogy maga a stratégia-épités folyamata valamit segíthet a területi identitás alakításában, egyes jegyeinek megteremtésében. A területfejlesztés 
szereplöinek közös gondolkodása, jövőjük térbeli feltételeinek együttes alakítása új akciótereket nyithatnak meg, növelhetik a másik szereplő (s egyben területi dimenzió), település problémái iránti érzékenységet, s szélesíthetik azok megoldásának módjait.

\section{Az elfogadás a stratégia halála?}

Ha a szereplők a stratégia-építés során döntően csak saját helyzetük megítélésével vannak elfoglalva, a koncepcionális fejezetekröl (küldetés, célok, célcsoportok), éppen a térségi ismeretek és azonosulás miatt nem képesek határozottan véleményt formálni, akkor a célok miként érvényesülnek az elfogadás ünnepi pillanatai után? A jelenlegi kialakuló struktúrában sajnos éppen az elfogadás jelenti a „stratégia halálát", annak elhallgatását, érvényességének negligálását. Törvényi szinten sem szabályozott az érvényesség garantálásának kérdése, ugyanakkor, mint láttuk gyenge az azonosulás szintje, s mindezt még fokozhatja, hogy nagyon lassan rendezödik a területi menedzsment helyzete, intézménye. Nincs olyan szervezet, amelynek érdeke jól, vagy rosszul érvényesíteni az elfogadott jövőképet. Azt tapasztaljuk, hogy a stratégiák kidolgozását ebben a kezdeti szakaszban még a törvényi kényszer mozgatja, nem az a valós igény, hogy miként lehetne a területi szerkezetet megújitani, miként lehet annak erőforrásait másként, jobban az ott élök érdekében hasznositani, megmozgatni.

A jövő cáfolni fogja majd pesszimista sejtésünket. Mindenesetre megindult valami a területi szereplök gondolkodásában, cselekvésében, ezek a folyamatok a korábbiakhoz képest elmozdulást mutatnak. Vélhetően a kutató nyugtalansága és a valóság változása közötti ütemkülönbségekböl következnek fenti kedvezötlen megállapításaink.

A területi szinten a jelenlegi rendszerben egyáltalán nem megoldott a tervekben foglalt célokhoz rendelt különféle (nemzetközi, központi, ágazati, területi) támogatások felhasználásának ellenőrzése, de annak regisztrálása sem, hogy az adott területen (térség, megye, kistérség) milyen forrásokat és kik használtak fel, éppen a párhuzamosságok, a keresztfinanszírozás számbavétele miatt. Emellett még nem rendelkezhetünk információkkal (egy év tapasztalatai alapján) arról, hogy a decentralizált területfejlesztési források milyen fejlesztési hatásokat indukáltak, egyáltalán miként érvényesültek.

\section{Stratégia, programozás és területrendezés}

A stratégiai szemléletü területi tervezés - összefoglalásként - abban különbözik a hagyományos - koncepcionális - tervezéstől, hogy az

- jövóbe tekintô: a hosszú távú gondolkodást és cselekvést szorgalmazza, a területrendszer lehetséges jövőképét határozza meg;

- kreatív: több jövőképet (forgatókönyv-elemzés) vázol fel, amiben az egyes szereplők jövőképe is megjelenik, a választás lehetőségét biztosítja, a dőntést szereplökre bízza, ezzel visszahat azok stratégiájára;

- rugalmas: a célok közötti átjárhatóságot kívánja biztosítani, a rendszer adaptációs képességének, s egyben irányítása biztonságának növelésével; 
- aktív: feladata a területrendszer egészének és egyes alkotóinak felkészítése a változásra, $\mathrm{s}$ az arra való reagálásra;

- akciókra épit: rendszerelemek komplex átalakitása, megvalósitás eszköze a célokhoz rendelt programok, amelyek maguk is változhatnak a célokkal együtt; változás-orientált: nem a meglévö intézmény- és eszközrendszerben gondolkodik, azoknak a célokhoz történö folyamatos igazitását kezdeményezi; siker-orientált: a dinamikát és a fejlödést helyezi elötérbe, azok feltételeinek a kialakítását szorgalmazza, a rendszerelemek jobb müködési feltételeivel, egyben a saját megújitásuk ösztönzésével (szereplöi stratégiák befolyásolása, azok módositása a területi összefüggések határozottabb érvényesítésével).

A programozás feladata mindezek után az elfogadott célok és célcsoportokhoz rendelhetö objektumok és intézmények, illetve beavatkozási módok meghatározása. A programok tehát a célok megvalósitásának rendszerezett gyüjteményei, olyan intézkedések - illetve ajánlások - sorozata, amit a területfejlesztés egyes szereplöi valósítanak meg a különféle - feltárt, rendszerezett - forrásokból. A programok kerülnek a jövöben finanszirozásra, amelyekhez különféle pénzügyi források rendelödnek, éppen a stratégiai célokban elfoglalt helyzetük alapján, s azokban más és más arányban szerepelnek a közösségi és a magán (piaci) hozzájárulások.

A területrendezés ezeknek a programoknak a térbeli megjelenitését segiti, azaz meghatározza azokat a terület-felhasználási módokat és szabályokat, amik alapján éppen a stratégiában megjelölt környezeti-települési miliö alapján - a programobjektumok megvalósíthatók. Mindezek alapján az országos, a térségi (regionális), a megyei területrendezési tervek tartalma nem egyértelmü, sőt mondhatni kevésbé értelmezhetö. Szükségesek viszont ajánlások a terület-felhasználás különféle módjaira vonatkozóan, hasonlóan nélkülözhetetlen térségi szinten kijelölni az ökológiai folyósokat, meg kell óvni a települési értékeket, s az új infrastrukturális csatornák felvázolása szintén elengedhetetlen térségi (regionális) szinten. Viszont a konkrét - megvalósitást kezdeményezö szereplövel rendelkezö - programok nélkül ennél mélyebb - szabályozókat tartalmazó - területrendezési tervet késziteni annyi, mint a tengerparton dagály elött homokvárat építeni.

A területi stratégiaépités során a területi egység táji, környezeti, építészeti adottságai keretfeltételként szerepelnek, így jelen kell lenniük a célok értelmezésénél, azok tartalmának meghatározásánál és értelemszerüen a programok alakításánál is. Nem kerülhet ellentmondásba a területi stratégia a területhasznositással, mert ha mégis, akkor nem reális maga a jövőkép, annak megvalósitása lehetetlen. Ugyancsak nem lehetséges területi stratégiát kidolgozni úgy, hogy a területhasználat minden formáját, valamilyen más elv - ami lényegében egy másik stratégia, egy másik jövökép - alapján már meghatározták.

A területi tervezésben az egyes alkotóelemeket - s ez is a kezdeti szakasz következménye - a helyükre kell tenni, ez a korábbi szerepek, befolyások átrendezödését jelenti, de mindez szükségszerüen együtt jár magának a területi politikának, eszköz-és intézményrendszerének megkezdett átalakitásával.

\section{Jegyzetek}

${ }^{1}$ Az elöadás A területi tervezés új kihivása: a területfejlesztési koncepció c. konferencián hangzott el. (Gyôr, 1997. április 3-4.) 